REPORTS OF MORPHOLOGY
Official Journal of the Scientific Society of Anatomists,
Histologists, Embryologists and Topographic Anatomists
of Ukraine
journal homepage: https://morphology-journal.com

\title{
Gallbladder cholesterolosis in patients with metabolic syndrome and chronic pancreatitis
}

\author{
Petrushenko V.V. ${ }^{1}$, Grebeniuk D.I. ${ }^{1}$, Liakhovchenko N.A. ${ }^{1}$, Gormash P.P. ${ }^{2}$
}

${ }^{1}$ National Pirogov Memorial Medical University, Vinnytsya, Ukraine

${ }^{2}$ Utility non-profit enterprise "Vinnitsa Regional Pathological Bureau of Vinnitsa Regional Council", Vinnytsya, Ukraine

\section{ARTICLE INFO}

Received: 16 December, 2020

Accepted: 19 January 2021

UDC: $616.366-006.5-07-089.87+616-$ $056.527+616.37-002$

\section{CORRESPONDING AUTHOR}

e-mail: doctor.svo@gmail.com

Grebeniuk D.I.

\begin{abstract}
Cholesterolosis, as a pathological condition caused by metabolic disorders, is potentially associated with metabolic syndrome and chronic pancreatitis. The aim of the study was to assess the prevalence and morphological features of gallbladder cholesterolosis in the contingent of patients with metabolic syndrome and chronic pancreatitis. 82 patients who underwent cholecystectomy for chronic calculous cholecystitis were included in our study. The experimental group consisted of 37 patients with metabolic syndrome and chronic pancreatitis. The comparison group included 45 patients without clinically confirmed metabolic syndrome and chronic pancreatitis. In accordance with the purpose and objectives, morphological examination of the gallbladder wall was performed. Data to be analyzed were processed using the statistical software package SPSS 20.0 for Windows. The gender and age structure of the studied contingent did not differ from that described in the scientific literature. The morphological picture of cholesterolosis did not differ in the study groups. In a mucous membrane considerable polymorphism of folds (villi) was noted. There were signs of desquamation and regeneration in the epithelium. There was a violation of the structure RokitanskyAschoff sinuses. In some crypts microconcretions were defined. Atrophy and sclerosis of the stroma of the villi were detected in the mucous membrane. Significant expansion of the lumen of the veins in the own plate of the mucous membrane and the perimuscular layer of the gallbladder wall was noteworthy. Signs of stasis were found in the lumen of blood vessels. The lumen of the arteries was narrowed in places due to swelling and accumulation of yellow-brown pigment. Signs of spasm and significant sclerosis of the wall were identified. Dystrophic changes in the endothelium contribute not only to the development of uneven plethora of stagnant nature with significant edema, but also hemorrhage. Significant swelling of all layers was characteristic, causing their disintegration. Significant dilation of lymphatic vessels causes a significant thickening of the gallbladder wall. In some places, there is uneven hypertrophy of the muscle layer. There was an excessive increase in the tortuosity ducts of Luschka. According to the study, patients with metabolic syndrome and chronic pancreatitis, operated on for chronic calculous cholecystitis, along with maintaining the gender and age structure of the contingent, there is a significantly higher incidence of gallbladder cholesterolosis. Keywords: gallbladder cholesterolosis, metabolic syndrome, chronic pancreatitis, morphology.
\end{abstract}

Interest in this problem has increased especially in the last two decades, when research began to appear aimed at clarifying the etiopathogenetic mechanisms of this pathology. This served as an impetus for the development of diagnostic criteria, tactics of such patients and methods of treatment [29].

The frequency of detection of this pathology, according to various authors, varies in an extremely wide range - from 
$3-5 \%$ to $50 \%$ or more $[7,18]$. This fact can be explained both by the difficulty and specificity of diagnostic measures, and the lack of clear protocols for early detection of cholesterolosis [31].

Cholesterolosis can be localized in the form of a "cholesterol polyp", or have a diffuse spread in the mucous membrane [16]. In addition, the changes inherent in cholesterolosis include signs of many local pathological processes. Thus, in the literature there are no clear differential differences between "cholesterol polyp" and sclerosed and deformed villi (folds) [26].

The development of cholesterolosis is associated with disorders of lipid metabolism [1, 25]. At the same time, such disorders accompany the development of metabolic syndrome [11, 14, 17, 19, 22, 23], the relationship of which with cholesterolosis is currently well studied [8, 12].

Without creating a direct significant negative impact on the general condition of the body, gallbladder cholesterolosis is a risk factor for a number of serious diseases. Thus, the role of this pathology in the development of acute pancreatitis has been proven [3, 20]. Acute pancreatitis, in turn, leads to a significant increase in the risk of developing chronic pancreatitis and pancreatic cancer $[10,13,15,28,30]$. There are some conflicting views in the literature regarding the association of cholesterolosis with gallbladder cancer. Some studies show a direct link between the frequency of cholesterolosis findings and the development of a neoplastic process in the gallbladder [4], other studies indicate an extremely low incidence of gallbladder cancer in this group of patients [21].

The incompletely studied pathogenetic and clinicallaboratory connections of gallbladder cholesterolosis with metabolic pathology and diseases of the gastrointestinal tract encourage research in this area. In our opinion, the study of gallbladder cholesterolosis in patients with metabolic syndrome and chronic pancreatitis is relevant.

The aim of the study was to assess the prevalence and morphological features of gallbladder cholesterolosis in the contingent of patients with metabolic syndrome and chronic pancreatitis.

\section{Materials and methods}

Prospective clinical research was performed at the Department of Endoscopic and Cardiovascular Surgery of National Pirogov Memorial Medical University, Vinnytsya on the basis of the Clinical Highly Specialized Surgical Center with Minimally Invasive Technologies of Vinnytsia Regional Clinical Hospital named after M.I. Pyrogov.

According to the purpose and objectives, the study included 82 patients who underwent cholecystectomy for chronic calculous cholecystitis. The mean age of patients was $57.0 \pm 13.2$ years. There were 58 women $(70.73 \%)$ and 24 men $(29.27 \%)$ in the studied contingent.

The experimental group consisted of 37 patients with metabolic syndrome and chronic pancreatitis. The comparison group included 45 patients without clinically confirmed metabolic syndrome and chronic pancreatitis.

The gallbladder, removed by cholecystectomy, was dissected lengthwise after surgery, the contents removed, and flushed with running water. Macroscopic changes in the shape, size, condition of the mucous membrane were described in the postoperative protocol. Signs of cholesterolosis were considered to be the presence of a yellow mesh in the mucous membrane on a red background. The prevalence of the described changes more than 2 centimeters was diagnosed as diffuse cholesterolosis, at smaller sizes - as focal. Attention was drawn to the presence of polyps. Given that the mucosa is normally velvety, not smooth, the assessment of polyps on examination of the mucosa is subjective, as polyps may be small, smaller than normal villi, so polyposis cholesterolosis is best diagnosed by histological examination.

After macroscopic examination, the gallbladder was fixed in a $10 \%$ solution of neutral formalin. After fixation for 3 days, gallbladder preparations were prepared according to standard methods. Paraffin sections 5-7 ?m thick were stained with hematoxylin and eosin. Microscopy and photographing of histological specimens were performed using a light microscope OLIMPUS BX 41 at magnifications of $40,100,200,400$ and 1000 times. Image acquisition and processing, as well as morphometry were performed using the program "Quick PHOTO MICRO 2.3".

Data that were subject to statistical analysis were processed using the statistical software package SPSS 20.0 for Windows.

\section{Results}

The mean age of patients in the experimental group was $56.8 \pm 12.5$ years. There were 26 women in the group $(70.27 \%), 11$ men $(29.73 \%)$. The mean age of patients in the comparison group was $57.1 \pm 13.9$ years. There were 32 women $(71.11 \%)$ in the group, 13 men $(28.89 \%)$.

Regarding the prevalence of cholesterolosis in the studied group of patients, in the experimental group of such patients there were $15(40.54 \%)$, in the comparison group - $8(17.8 \%)$. The differences between the groups were statistically significant $(p<0.05)$.

When analyzing the sex distribution of patients with cholesterolosis, it was found that in the experimental group there were $9(60 \%)$ women and $6(40 \%)$ men, and in the comparison group - 6 (75\%) women and 2 (25\%) men. Statistically significant differences were not proved $(p>0.05)$.

Regarding the dependence of the incidence of gallbladder cholesterolosis on the age of patients, we did not find any statistically significant patterns.

In the morphological study in both the experimental group and the comparison group, the following changes were observed.

In patients operated on for chronic calculous cholecystitis by examination microscopy of the gallbladder wall (bottom of the body and neck) found quite similar 


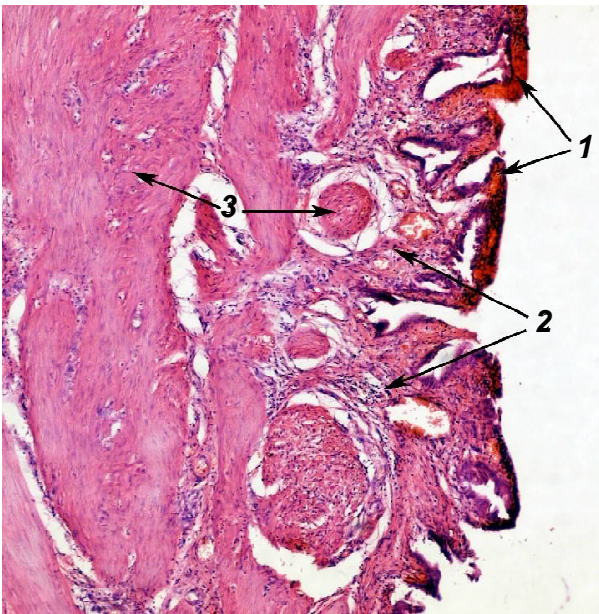

Fig. 1. Lack of a clear boundary between the mucous membrane (1) perimuscular (2) and the muscular structural elements (3) of the gallbladder wall. Hematoxylin-eosin. x100.

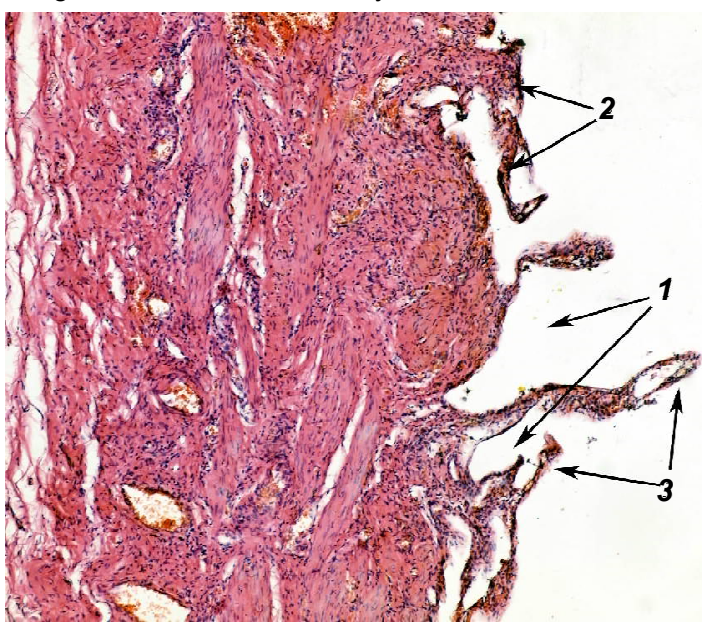

Fig. 2. Uneven narrowing and widening of the lumen of the crypt of the mucous membrane (1), sclerosis of the stroma of the villi (2), on the surface of which the epithelium is flattened or absent (3). Hematoxylin-eosin. x100.

morphological changes that differ only in depth, distribution and ratio. Thus, in the wall of the gallbladder of all areas there are significant violations of all layers, which is manifested by the disintegration of the classical ratio of membranes due to the unevenness of inflamed atrophic, hypertrophic, sclerotic and hemodynamic processes (Fig. 1).

The mucous membrane acquires especially significant changes in the conditions of chronic calculous cholecystitis. In almost all cases, signs of cholesterolosis of varying severity, both in the mucous membrane and in other layers of the gallbladder wall. In the mucous membrane there is a significant polymorphism of folds (villi), which are presented in the form of both high and narrow, and wide and low structures. These structures are often deformed and lined, mainly with flattened cubic, less often prismatic, epithelium, under which significant sclerosis is often defined (Fig. 2).

There are signs of desquamation and regeneration in the epithelium. The latter is manifested by a layering of cellular elements with hyperchromia of the nuclei. Normally, the glandular structures of the mucous membrane (crypts) are placed vertically with a certain frequency, depending on the location (bottom, body, neck). They are lined with prismatic mucus-forming epithelium, which provides a mucus-forming function aimed at liquefying bile. In our observations, a significant violation of the structure of the crypts and Rokitansky-Aschoff sinuses draws attention. They are significantly deformed, often cystically enlarged, and the epithelium lining them is either flattened or absent at a great distance due to its desquamation (Fig. 3).

In some crypts on the surface of the epithelium or in the lumen are defined by dense orange mass of irregular shape (microconcretions) (Fig. 4).

In the cytoplasm of cells, the surface of the villi and crypts, where the epithelium is absent, as in epithelial cells, are determined by dusty or granular inclusions of brownish-

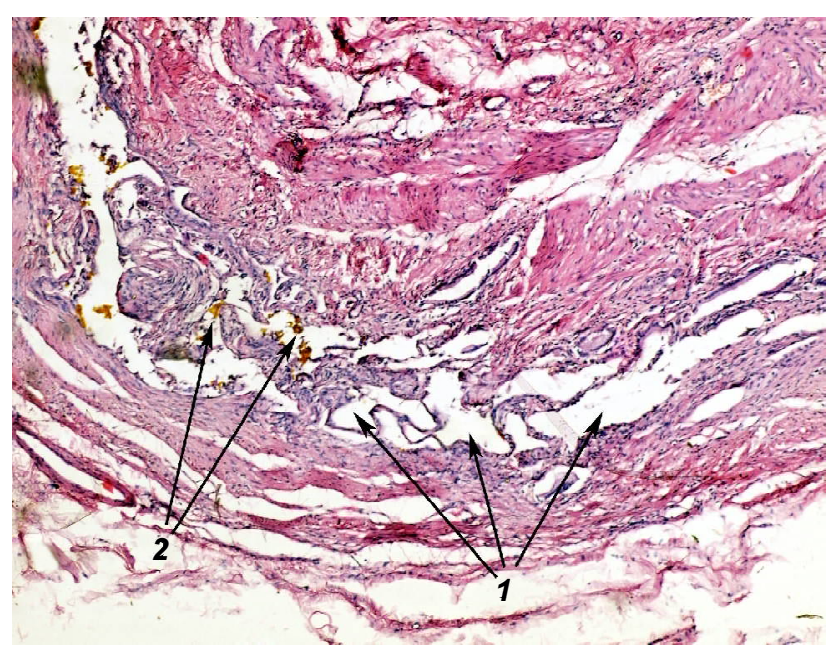

Fig. 3. Cystic enlargement and deformation of the RokitanskyAschoff sinuses (1), in desquamated epitheliocytes pigment inclusion (2). Hematoxylin-eosin. x100.

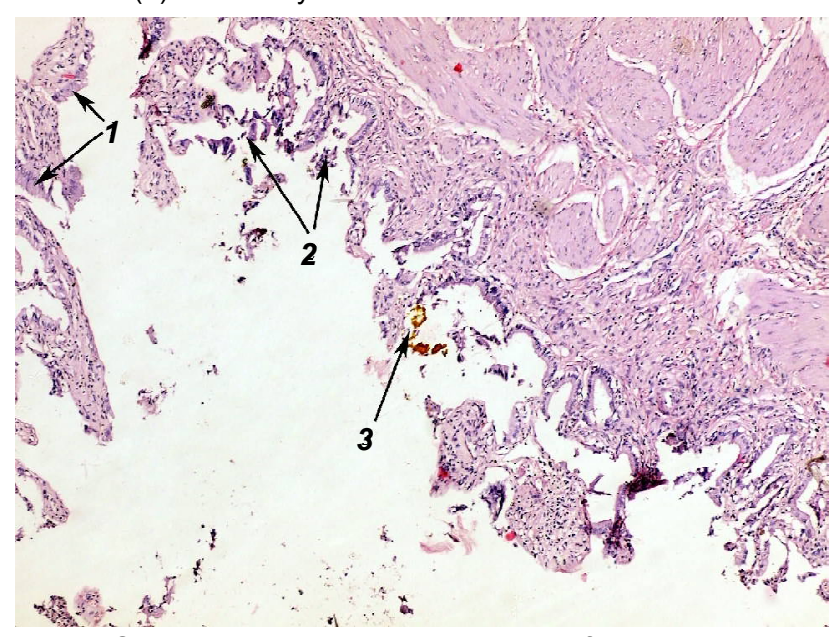

Fig. 4. Swelling (1) and desquamation (2) of the crypt mucosa epithelium of the gallbladder, fixed unstructured masses (microconcretions) of orange color (3) in place of the desquamated epithelium. Hematoxylin-eosin. x200. 


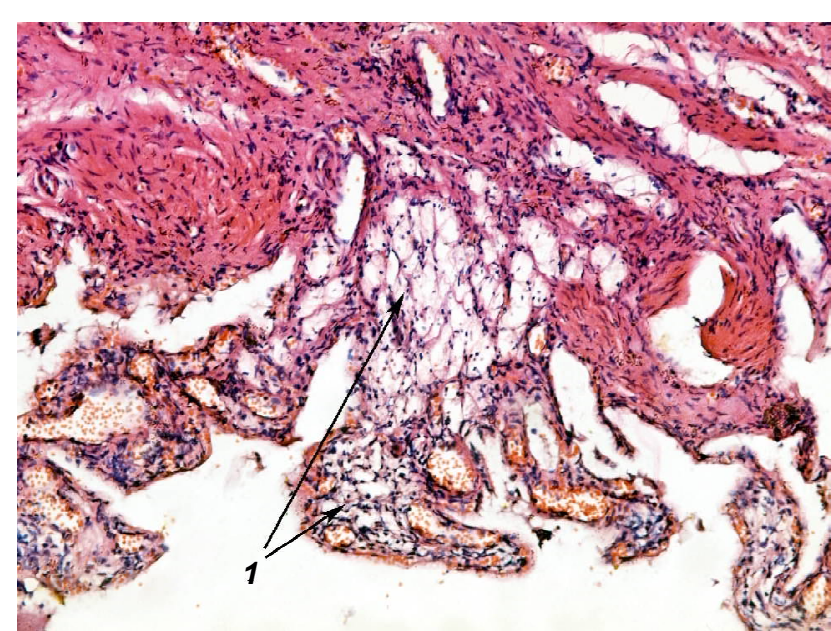

Fig. 5. Numerical xanthoma cells (1) in the stroma of villi. Hematoxylin-eosin. x200.

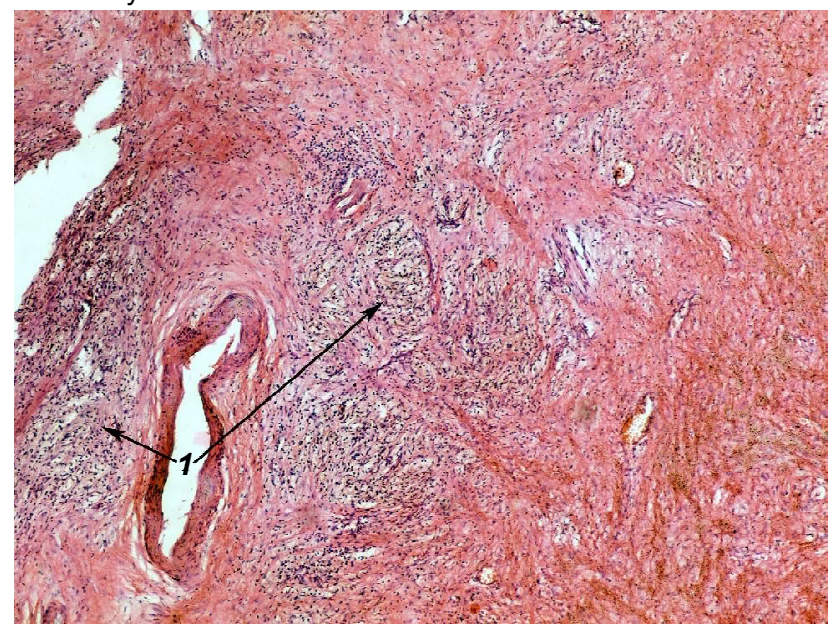

Fig. 6. Focal lympho-histiocytic infiltration (1), by type of xanthogranuloma. Hematoxylin-eosin. x200.

brown color. There are accumulations of desquamated epithelium among the condensed yellow bile, which also differs from the normal accumulation of pigment (xanthoma cells). In the mucous membrane is constantly detected atrophy and sclerosis of the stroma of the villi (folds), which is represented by fibroblasts and densely spaced collagen fibers, between which there are "foamy" cells and lymphocytes (Fig. 5). Accumulations of such cells in some patients are found in the adventitia and in the muscle layer.

Blood vessels in the stroma of the villi are sometimes not identified. As for the own plate of the mucous membrane, the number of blood vessels in the microcirculatory tract is uneven. In some cases, they are more than normal, in others - they are almost absent. Draws attention to the significant expansion of the lumen of the veins in its own plate of the mucous membrane and the perimuscular layer of the gallbladder wall. Signs of stasis and uneven distribution of cellular elements (erythrocytes) and plasma are found in the lumen of blood vessels of different calibers, which is a morphological reflection of gallbladder wall dystonia. As for the arteries, which are known to be mainly localized in the perimuscular layer, their lumen is narrowed in places due to swelling and accumulation of yellow-brown pigment. There is a recalibration of the arteries in the direction of reducing the caliber, due to swelling and proliferation of endothelial cells. Signs of spasm and significant sclerosis of the wall are identified. In some vessels, endothelial cells in the presence of dystrophy significantly narrow the lumen and contribute to the development of stasis, and sometimes fragmentarily obliterate it over a fairly long period.

Dystrophic changes in the endothelium contribute not only to the development of uneven plethora of stagnant nature with significant edema, but also hemorrhage. Xanthoma cells are also found in arterioles, the obliteration of which is accompanied by wall necrosis, and sometimes causes the development of small foci of fibrinoid necrosis in the surrounding tissues, which is more common in gallbladder adventitia. Focal changes of an alternative nature initiate the development of inflammatory, focal or diffuse infiltration mainly by mononuclear cells: lymphocytes, histiocytes, macrophages. Structures resembling xanthoma granulomas are formed (Fig. 6).

Gallstone disease and cholesterolosis are characterized by significant swelling of all layers, which causes their disintegration. Significant dilation of lymphatic vessels causes a significant thickening of the gallbladder wall. Numerous lipid patches were sometimes observed in the lumen of the lymphatic vessels of the adventitia (Fig. 7).

In some places, there is uneven hypertrophy of the muscle layer. Smooth muscle fibers are unevenly stained with eosin. Their cytoplasm is often vacuolated.

In some cases, especially large lacunae of edematous fluid are found in the mucous membrane's own plate and in the muscular layer, which cause disintegration of tufts by drag, which have different thickness, different direction with predominance of muscle bundles in the transverse (circular) direction. Muscle fiber dystrophy is evidenced by the

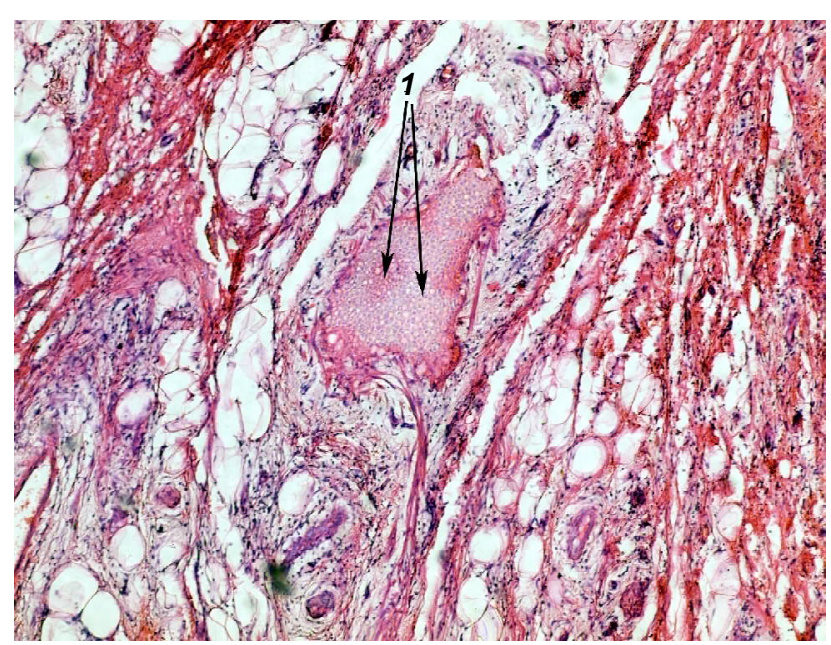

Fig. 7. Numerous lipid droplets (1) in the lumen of the dilated lymphatic vessel of the gallbladder adventitia. Hematoxylin-eosin. $\mathrm{x} 100$. 


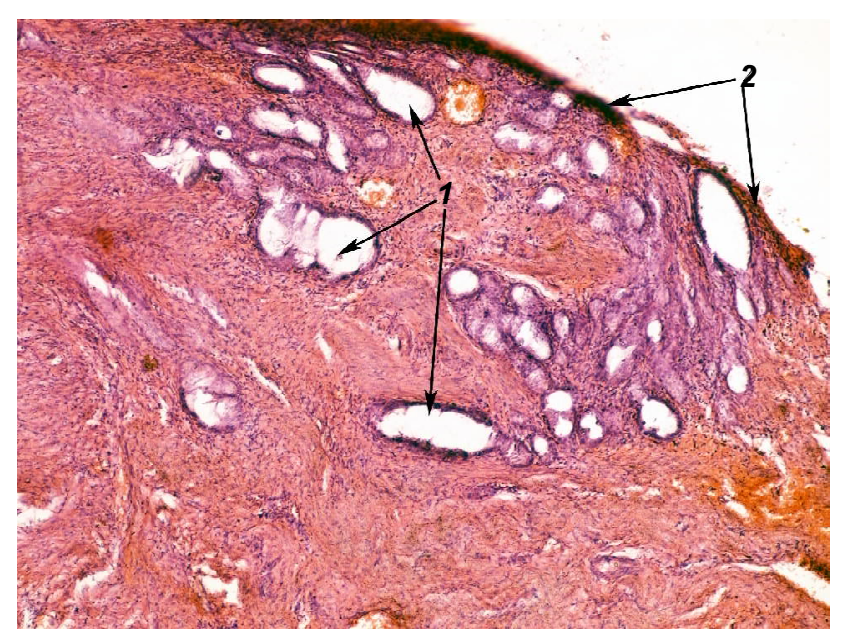

Fig. 8. Localized in the muscular layer dilated glands (1) lined with prismatic epithelium on the background of atrophy of the mucous membrane (2). Hematoxylin-eosin. x100.

heterogeneous intensity of sarcoplasmic staining and hypochromia of the nuclei. In other cases, the muscle layer is represented by densely spaced bundles of fibers that are unevenly bounded by fibrous tissue. Swelling in such cases is insignificant or absent. There are fields of fibrous tissue with signs of hyalinosis. Rarely, single tubular-type glands with a dense basement membrane, with moderate lumen enlargement and swelling of the epithelium or foci of pseudoadenomatosis are identified in the muscular layer, represented by clusters of tubular-type glands lined with cubic epithelium (Fig. 8). There is an excessive increase in the tortuosity of ducts of Luschka.

\section{Discussion}

The pathogenesis of gallbladder cholesterolosis is characterized by the presence of a large number of links in pathological processes, and their relationship is not fully described in the modern scientific literature [31].

In our study, no age-specific features of the development of gallbladder cholesterolosis were found, and the sex distribution showed results similar to those described in the scientific literature [7].

Instead, it was confirmed that patients with metabolic syndrome and chronic pancreatitis have a higher incidence of gallbladder cholesterolosis. It is known that the metabolic syndrome is accompanied by a violation of all types of metabolism [1, 25]. Changes in metabolism, of course, are reflected in the qualitative and quantitative composition of bile [8, 12], which can, at least in part, contribute to the development of changes in the gallbladder.

As for the relationship between chronic pancreatitis and gallbladder cholesterolosis, it is still difficult to unambiguously determine the root cause of the changes. The anatomical unity of the hepatopancreatobiliary system determines the simultaneous and parallel development of pathological processes in the liver, biliary tract and pancreas. Changes in one part of this system contribute to physiological and anatomical disorders in the activities of others. That is why, on the one hand, fibrosis of the tissues of the pancreas can disrupt the outflow of bile from the gallbladder, followed by the creation of favorable conditions for the formation of stones. On the other hand, changes in the gallbladder wall lead to increased formation of stones in its lumen and are often the cause of episodes of acute pancreatitis, which is known to further lead to the development of chronic pancreatitis [3, 20].

Therefore, further research with the definition of parallels between the pathogenetic links of the metabolic syndrome, chronic pancreatitis and gallbladder cholesterolosis is promising.

Regarding the morphological aspects of the study, we could not prove significant differences between the studied groups.

The formation of pseudo-adenomatous structures in the muscular layer, in our opinion, is associated with an excessive increase in the tortuosity of ducts of Luschka, which is possible with sclerosis, atrophy and a decrease in the thickness of the gallbladder wall. Ducts of Luschka are not known to be associated with the secretion of bile by the bile ducts, they are directed towards the bile ducts of the liver and flow directly into them. The formation of such adenomatous structures is a clear morphological sign of bile flow blockade in them. Unfortunately, the functional purpose of ducts of Luschka, which connect with the bile ducts of the liver in the periodical literature is insufficiently described $[6,24]$ : these are alternative structures of outflow or inflow of bile into the gallbladder.

In the pathogenesis of atrophy and sclerosis of the mucous membrane and other layers of the gallbladder in chronic calculous cholecystitis and cholesterolosis, most authors attach importance to the violation of lipid metabolism and inflammation [8, 12]. We agree with this opinion, but pay attention to changes in blood vessels of all layers of the gallbladder wall due to selective and uneven cholesterolosis - ie the accumulation of bile pigments in endothelial cells and pericytes of both large vessels and vessels of the microcirculatory tract. Due to the above changes in blood vessels, there is a redistribution of blood in the microcirculatory tract, arteries and veins. The latter are sometimes significantly expanded with signs of stasis. Dystrophic changes in the endothelium, in our opinion, contribute not only to the development of uneven plethora of stagnant nature with significant edema, but also hemorrhage, which in turn leads to the progression of sclerotic processes.

In all cases of gallstone disease in combination with cholesterolosis, histological examination of the gallbladder wall revealed pronounced dystrophic and sclerotic processes that cause deformation of folds, atrophy of anastomoses, significant expansion of crypts and intercryptal canals (tunnels) with a decrease in the number of and epithelial atrophy.

The above-described signs of proliferative aseptic 
inflammation may be exacerbated by the development of gallbladder wall dystonia caused by peripheral nerve dystrophy, in the structure of which dust-like inclusions of yellow-brown pigment were also determined.

Such changes certainly take a long time to develop. Morphogenesis and pathogenetic mechanisms of their development in the complex can be difficult to assess. For example, in the periodical literature we did not find works that would determine the significance of impaired lymph circulation and significant edema of the gallbladder wall, which in some cases is excessive, and in others absent. It is known that the outflow of lymph in the gallbladder occurs in the same direction as the bile. Dyskinesia of the gallbladder wall certainly affects not only the evacuation of bile, but also the evacuation of lymph, the production of which is enhanced by hemodynamic disorders. Lymphostasis is known to exacerbate hypoxia and the development of sclerosis as a result of collagenization of reticular and elastic fibers [5]. This pathogenetic mechanism of progressive sclerosis, as well as the cellular synthesis of collagen fibers in the presence of inflammatory infiltration should be further investigated at the histochemical level.

According to the literature, epithelial lining of the surface of folds, crypts, their sinuses and existing tunnels between them normally provides the absorption of liquid components of bile and increase its concentration in the gallbladder, as in the bile depot $[9,32]$. With the spread of desquamation of the prismatic epithelium and its atrophy, metaplasia in the multilayered squamous function of absorption and concentration of bile and regulation of its biochemistry

\section{References}

[1] Bhatta, S., \& Singh, S. (2018). Study of gallbladder lesions and its relationship with serum lipid profile. International Journal of Advances in Medicine, 5(5), 1245. doi:10.18203/23493933.ijam20183902

[2] Corradini, S.G., Elisei, W., Giovannelli, L., Ripani, C., Della Guardia, P., Corsi, A. ... Attili, A.F. (2000). Impaired human gallbladder lipid absorption in cholesterol gallstone disease and its effect on cholesterol solubility in bile. Gastroenterology, 118(5), 912920. https://doi.org/10.1016/s0016-5085(00)70177-6

[3] De Armas, R.E., Rosenberg, J.M., \& Fenves, A.Z. (2018). Cholesterolosis as a cause of acute pancreatitis. Proceedings (Baylor University. Medical Center), 31(3), 324-325. https:// doi.org/10.1080/08998280.2018.1460128

[4] Dilek, O.N., Karasu, S., \& Dilek, F.H. (2019). Diagnosis and Treatment of Gallbladder Polyps: Current Perspectives. Euroasian Journal of Hepato-Gastroenterology, 9(1), 40-48. https://doi.org/10.5005/jp-journals-10018-1294

[5] Godoy, M., Buzato, E., Brigidio, P.A., \& Pereira de Godoy, J.M. (2012). Is lymphostasis an aggravant of lipedema? Case Reports in Dermatology, 4(3), 222-226. https://doi.org/10.1159/ 000342073

[6] Gomez, N.A., \& Gutierrez, J.O. (2017). Ducts of Luschka: A Review. Clinics in Surgery, 2, 1-3.

[7] Holanda, A., \& Lima Junior, Z.B. (2020). Gallbladder histological alterations in patients undergoing cholecystectomy for cholelithiasis. Alteracoes histologicas da vesicula biliar de decreases, while suppressing the mucus-forming function of the epithelium, which aims to thin bile $[2,27]$. Deficiency of this function may also play a role in changes in bile composition and the development of chronic calculous cholecystitis. This opinion is confirmed by compensatory swelling of a prismatic epithelium in separate saved sinuses of crypts. With a reduced number of crypts and their sinuses, changes in their lumen and desquamation of the epithelium, this function is suppressed. Similarly, the mucus-forming function on the surface of the folds is suppressed, especially if the surface of the villi, which is represented by xanthoma cells is not of epithelial origin.

Thus, the morphological changes of the gallbladder wall in chronic calculous cholecystitis with cholesterolosis are diverse, as well as the pathogenetic mechanisms of their development and require in-depth study to select and improve adequate treatments. In addition, the relationship between the development of metabolic syndrome and gallbladder cholesterolosis requires further careful study.

\section{Conclusions}

1. According to the morphological study in patients with metabolic syndrome and chronic pancreatitis, operated on for chronic calculous cholecystitis, along with the preservation of the sex and age structure of the contingent, there is a significantly higher incidence of gallbladder cholesterolosis.

2. Further research with the definition of parallels between the pathogenetic links of the metabolic syndrome and chronic pancreatitis and the development of gallbladder cholesterolosis is promising.

doentes submetidos a colecistectomia por colelitiase. Revista do Colegio Brasileiro de Cirurgioes, 46(6), e20192279. https:/ /doi.org/10.1590/0100-6991e-20192279

[8] Jung, K.W., Koh, A.R., Kim, C.H., Bang, J.H., \& Lee, J.H. (2018). Risk Factors of Gallbladder Polyp, and Association between Gallbladder Polyp and Dyslipidemia in Health Examines. Korean J. Fam. Pract., 8, 703-708. https://doi.org/10.21215/ kjfp.2018.8.5.703

[9] Kim, E.Y., \& Hong, T.H. (2020). Bile cholesterol and viscosity, the keys to discriminating adenomatous polyps from cholesterol polyps by a novel predictive scoring model. BMC Gastroenterology, 20(1), 268. https://doi.org/10.1186/s12876020-01414-9

[10] Kirkegard, J., Cronin-Fenton, D., Heide-Jorgensen, U., \& Mortensen, F.V. (2018). Acute Pancreatitis and Pancreatic Cancer Risk: A Nationwide Matched-Cohort Study in Denmark. Gastroenterology, 154(6), 1729-1736. https://doi.org/10.1053/ j.gastro.2018.02.011

[11] Lee, M.K., Han, K., Kim, M.K., Koh, E.S., Kim, E.S., Nam, G.E., \& Kwon, H.S. (2020). Changes in metabolic syndrome and its components and the risk of type 2 diabetes: a nationwide cohort study. Scientific Reports, 10(1), 2313. https://doi.org/ 10.1038/s41598-020-59203-z

[12] Leng, S., Zhao, A., Li, Q., Pei, L., Zheng, W., Liang, R., \& Yan, H. (2018). Metabolic status and lifestyle factors associated with gallbladder polyps: a covariance structure analysis. BMC 
Gastroenterology, 18(1), 159. https://doi.org/10.1186/s12876018-0882-z

[13] Liu, J., Wang, Y., \& Yu, Y. (2020). Meta-analysis reveals an association between acute pancreatitis and the risk of pancreatic cancer. World Journal of Clinical Cases, 8(19), 4416-4430. https://doi.org/10.12998/wjcc.v8.i19.4416

[14] Ma, A., Fang, K., Dong, J., \& Dong, Z. (2020). Prevalence and Related Factors of Metabolic Syndrome in Beijing, China (Year 2017). Obesity Facts, 13(6), 538-547. https://doi.org/10.1159/ 000508842

[15] Machicado, J.D., \& Yadav, D. (2017). Epidemiology of Recurrent Acute and Chronic Pancreatitis: Similarities and Differences. Digestive Diseases and Sciences, 62(7), 1683-1691. https:/ /doi.org/10.1007/s10620-017-4510-5

[16] Mellnick, V.M., Menias, C.O., Sandrasegaran, K., Hara, A.K., Kielar, A.Z., Brunt, E.M. ... Elsayes, K.M. (2015). Polypoid lesions of the gallbladder: disease spectrum with pathologic correlation. Radiographics: a Review Publication of the Radiological Society of North America, Inc., 35(2), 387-399. https://doi.org/10.1148/rg.352140095

[17] Mendrick, D.L., Diehl, A.M., Topor, L.S., Dietert, R.R., Will, Y., La Merrill, M.A. ... Burleson, F.G. (2018). Metabolic Syndrome and Associated Diseases: From the Bench to the Clinic. Toxicological Sciences: an Official Journal of the Society of Toxicology, 162(1), 36-42. https://doi.org/10.1093/toxsci/ $\mathrm{kf} \times 233$

[18] Metman, M., Olthof, P.B., van der Wal, J., van Gulik, T.M., Roos, D., \& Dekker, J. (2020). Clinical relevance of gallbladder polyps; is cholecystectomy always necessary? HPB: The Official Journal of the International Hepato Pancreato Biliary Association, 22(4), 506-510. https://doi.org/10.1016/ j.hpb.2019.08.006

[19] Nilsson, P.M., Tuomilehto, J., \& Ryden, L. (2019). The metabolic syndrome - What is it and how should it be managed? European Journal of Preventive Cardiology, 26(2_suppl), 3346. https://doi.org/10.1177/2047487319886404

[20] Parrilla Paricio, P., Garcia Olmo, D., Pellicer Franco, E., Prieto Gonzalez, A., Carrasco Gonzalez, L., \& Bermejo Lopez, J. (1990). Gallbladder cholesterolosis: an aetiological factor in acute pancreatitis of uncertain origin. The British Journal of Surgery, 77(7), 735-736. https://doi.org/10.1002/ bjs. 1800770706

[21] Roa, I., de Aretxabala, X., Ibacache, G., \& Munoz, S. (2010). Colesterolosis y cancer de la vesicula biliar [Association between cholesterolosis and gallbladder cancer]. Revista Medica de Chile, 138(7), 804-808.

[22] Rochlani, Y., Pothineni, N.V., Kovelamudi, S., \& Mehta, J.L. (2017). Metabolic syndrome: pathophysiology, management, and modulation by natural compounds. Therapeutic Advances in Cardiovascular Disease, 11(8), 215-225. https://doi.org/ 10.1177/1753944717711379

[23] Saklayen M.G. (2018). The Global Epidemic of the Metabolic Syndrome. Current Hypertension Reports, 20(2), 12. https:// doi.org/10.1007/s11906-018-0812-z

[24] Schnelldorfer, T., Sarr, M.G., \& Adams, D.B. (2012). What is the duct of Luschka? - A systematic review. Journal of Gastrointestinal Surgery: Official Journal of the Society for Surgery of the Alimentary Tract, 16(3), 656-662. https://doi.org/ 10.1007/s11605-011-1802-5

[25] Stromsten, A., von Bahr, S., Bringman, S., Saeki, M., Sahlin, S., Bjorkhem, I., \& Einarsson, C. (2004). Studies on the mechanism of accumulation of cholesterol in the gallbladder mucosa. Evidence that sterol 27-hydroxylase is not a pathogenetic factor. Journal of Hepatology, 40(1), 8-13. https://doi.org/ 10.1016/s0168-8278(03)00502-6

[26] Taskin, O. C., Basturk, O., Reid, M. D., Dursun, N., Bagci, P., Saka, B. ... Adsay, V. (2020). Gallbladder polyps: Correlation of size and clinicopathologic characteristics based on updated definitions. PloS One, 15(9), e0237979. https://doi.org/ 10.1371/journal.pone.0237979

[27] Turumin, J.L., Shanturov, V.A., \& Turumina, H.E. (2013). The role of the gallbladder in humans. Revista de Gastroenterologia de Mexico, 78(3), 177-187. https://doi.org/10.1016/ j.rgmx.2013.02.003

[28] Uomo, G., \& Rabitti, P.G. (2000). Chronic pancreatitis: relation to acute pancreatitis and pancreatic cancer. Annali italiani di chirurgia, 71(1), 17-21.

[29] Vagholkar, K., Chandrashekhar, S., Singh, S., Narang, N., \& Bhadavankar, F. (2021) Cholesterolosis of the gall bladder: a surgical dilemma. Int. Surg. J., 8(1), 375-377. http://dx.doi.org/ 10.18203/2349-2902.isj20205409

[30] Weiss, F.U., Laemmerhirt, F., \& Lerch, M.M. (2019). Etiology and Risk Factors of Acute and Chronic Pancreatitis. Visceral Medicine, 35(2), 73-81. https://doi.org/10.1159/000499138

[31] Yaylak, F., Deger, A., Ucar, B. I., Sonmez, Y., Bayhan, Z., \& Yetisir, F. (2014). Cholesterolosis in routine histopathological examination after cholecystectomy: what should a surgeon behold in the reports?. International Journal of Surgery (London, England), 12(11), 1187-1191. https://doi.org/10.1016/ j.ijsu.2014.08.402

[32] Zhao, M.F., Huang, P., Ge, C.L., Sun, T., Ma, Z.G., \& Ye, F.F. (2016). Conjugated bile acids in gallbladder bile and serum as potential biomarkers for cholesterol polyps and adenomatous polyps. The International Journal of Biological Markers, 31(1), e73-e79. https://doi.org/10.5301/jbm.5000173

\section{ХОЛЕСТЕРОЗ ЖОВЧНОГО МІХУРА У ПАЦІЕНТІВ 3 МЕТАБОЛІЧНИМ СИНДРОМОМ ТА ХРОНІЧНИМ ПАНКРЕАТИТОМ \\ Петрушенко В.В., Гребенюк Д.І., Ляховченко Н.А., Гормаш П.П.}

Холестероз, як патологічний стан, що виникає внаслідок порушення обміну речовин, потенційно пов'язаний з метаболічним синдромом та хронічним панкреатитом. Мета дослідження - оцінити розповсюдження та вивчити морфологічні особливості холестерозу жовчного міхура у контингенті пацієнтів із метаболічним синдромом та хронічним панкреатитом. У дослідження було включено 82 пацієнти, яким була виконана холецистектомія з приводу хронічного калькульозного холециститу. Дослідну групу склали 37 пацієнтів із метаболічним синдромом та хронічним панкреатитом. $B$ групу порівняння ввійшли 45 пацієнтів без клінічно підтвердженого метаболічного синдрому та хронічного панкреатиту. Відповідно до мети та завдань, виконували морфологічне дослідження стінки жовчного міхура. Дані, які підлягали статистичному аналізу, обробляли за допомогою пакету статистичних програм SPSS 20.0 for Windows. Гендерно-вікова структура досліджуваного контингенту не відрізнялася від описаної в науковій літературі. Морфологічна картина холестерозу не відрізнялася у досліджуваних групах. В слизовій оболонці відмічався значний поліморфізм складок (ворсин). В епітелії траплялися ознаки десквамації та регенерації. Мало місце порушення будови крипт та синусів Рокитанського-Ашофрфа. В деяких криптах визначалися мікроконкременти. В слизовій оболонці виявлялася атрофія та склероз строми ворсинок. Звертало увагу значне розширення просвіту вен у власній пластинці слизової оболонки та перимускулярному шарі стінки жовчного міхура. В просвіті кровоносних судин 
виявлялися ознаки стазу. Просвіт артерій був місцями звужений через набухання та накопиченні пігменту жовто-коричневого кольору. Визначалися ознаки спазму та значного склерозу стінки. Дистрофрічні зміни в ендотелії сприяють не тільки розвитку нерівномірного повнокрів'я застійного характеру при значному набряку, а і крововиливам. Характерним був значний набряк всіх шарів, що спричиняє їх дезінтеграцію. Значне розширення лімфатичних судин зумовлює суттєве потовщення стінки жовчного міхура. Місцями спостерігається нерівномірна гіпертрофрія м'язового шару. Спостерігалося надмірне збільшення звивистості каналів Люшка. За даними дослідження у пацієнтів із метаболічним синдромом та хронічним панкреатитом, прооперованих з приводу хронічного калькульозного холециститу, поряд із збереженням гендерно-вікової структури контингенту, спостерігається достовірно вища частота зустрічаємості холестерозу жовчного міхура. Ключові слова: холестероз жовчного міхура, метаболічний синдром, хронічний панкреатит, морфологія. 